\title{
First occurrence of moskvinite-(Y) in the llímaussaq alkaline complex, South Greenland - implications for rare-earth element mobility
}

\author{
HENRIK FRIIS* \\ Natural History Museum, University of Oslo, PO 1172 Blindern, 0318 Oslo, Norway
}

[Received 24 May 2015; Accepted 16 July 2015; Associate Editor: Kathryn Goodenough]

\section{ABSTRACT}

Moskvinite-( $(\mathrm{Y}), \mathrm{Na}_{2} \mathrm{~K}(\mathrm{Y}, R E E) \mathrm{Si}_{6} \mathrm{O}_{15}$, is a rare mineral, which until now has only been described from its type locality Dara-i-Pioz, Tajikistan. At Ilímaussaq moskvinite-(Y) was discovered in a drill core from Kvanefjeld, where it occurs as a replacement mineral associated with a mineral belonging to the britholite group. The composition was determined by a combination of electron probe microanalysis and laser ablation inductively coupled plasma mass spectrometry analyses. The empirical formula based on 15 oxygens is $\mathrm{Na}_{1.94} \mathrm{~K}_{0.99}\left(\mathrm{Y}_{0.94} \mathrm{Yb}_{0.03} \mathrm{Er}_{0.03} \mathrm{Dy}_{0.03} \mathrm{Ho}_{0.01} \mathrm{Gd}_{0.01}\right)_{\sum 1.05} \mathrm{Si}_{5.98} \mathrm{O}_{15}$. The coexistence of an almost pure $\mathrm{Y}$ and a light rare-earth element $(R E E)$ mineral is interpreted as fractionation of $R E E$ and $\mathrm{Y}$ during the replacement of an earlier formed $R E E$ mineral. Theoretical calculations of the observed replacement of feldspathoids by natrolite show that the generated fluid would have $\mathrm{pH}>8$, which inhibits large scale mobility of REE. In addition, a K-Fe sulfide member of the chlorbartonite-bartonite group is for the first time observed in Ilímaussaq where it occurs where sodalite is replaced by natrolite and arfvedsonite by aegirine. The sulfide incorporates the $\mathrm{S}$ and some of the $\mathrm{Cl}$ generated by the alteration of sodalite, whereas the $\mathrm{K}$ and $\mathrm{Fe}$ originates from the replacement of arfvedsonite by aegirine.

KEYwords: moskvinite-(Y), REE mobility, bartonite group, Ilímaussaq alkaline complex.

\section{Introduction}

THE Ilímaussaq alkaline complex is situated in South Greenland and is among the youngest alkaline complexes in the region associated with the Gardar rifting (Upton, 2013) dated to $\sim 1.16 \mathrm{Ga}$ (Waight et al., 2002; Krumrei et al., 2006). Kvanefjeld is situated in the northern part of the complex (Fig. 1) and consists mostly of lujavrites, which are arfvedsonite- or aegirine-bearing sodalite and alkali feldspar, nepheline syenites (Ussing, 1912). Lujavrite is fine grained, with grains up to $0.6 \mathrm{~mm}$ but sodalite grains can be up to $2 \mathrm{~mm}$. In addition to the normal lujavrites, Ilímaussaq also contains naujakasite lujavrite and a mediumto-coarse grained lujavrite named m-c-lujavrite.

* E-mail: geofriis@yahoo.com

DOI: $10.1180 /$ minmag.2016.080.047
Lujavrite represents the last phase of the magmatic evolution of the Ilímaussaq complex resulting in high concentrations of critical elements, mostly hosted in steenstrupine-(Ce) and lovozerite-group minerals (e.g. Ussing, 1912; Ferguson, 1964; Sørensen, 1992; Sørensen et al., 2011).

In the 1950s Kvanefjeld was discovered as a potential U-deposit, which led to extensive drilling and exploration that culminated with a $1 \mathrm{~km}$ adit being made in 1980-81 (Sørensen, 2001). For political reasons the Kvanefjeld project was terminated in 1983. In 2007, Greenland Minerals and Energy Ltd initiated a new drilling campaign on Kvanefjeld. The new focus was on Kvanefjeld as a multi-element deposit with REEs as the main target metals together with $\mathrm{U}$ and $\mathrm{Zn}$. The former two metals are both hosted primarily in steenstrupine-(Ce), and the latter in sphalerite, which occurs in all of the lujavrites.

Moskvinite-(Y), ideally $\mathrm{Na}_{2} \mathrm{~K}(\mathrm{Y}, R E E) \mathrm{Si}_{6} \mathrm{O}_{15}$, was first described from the Dara-i-Pioz moraine in 


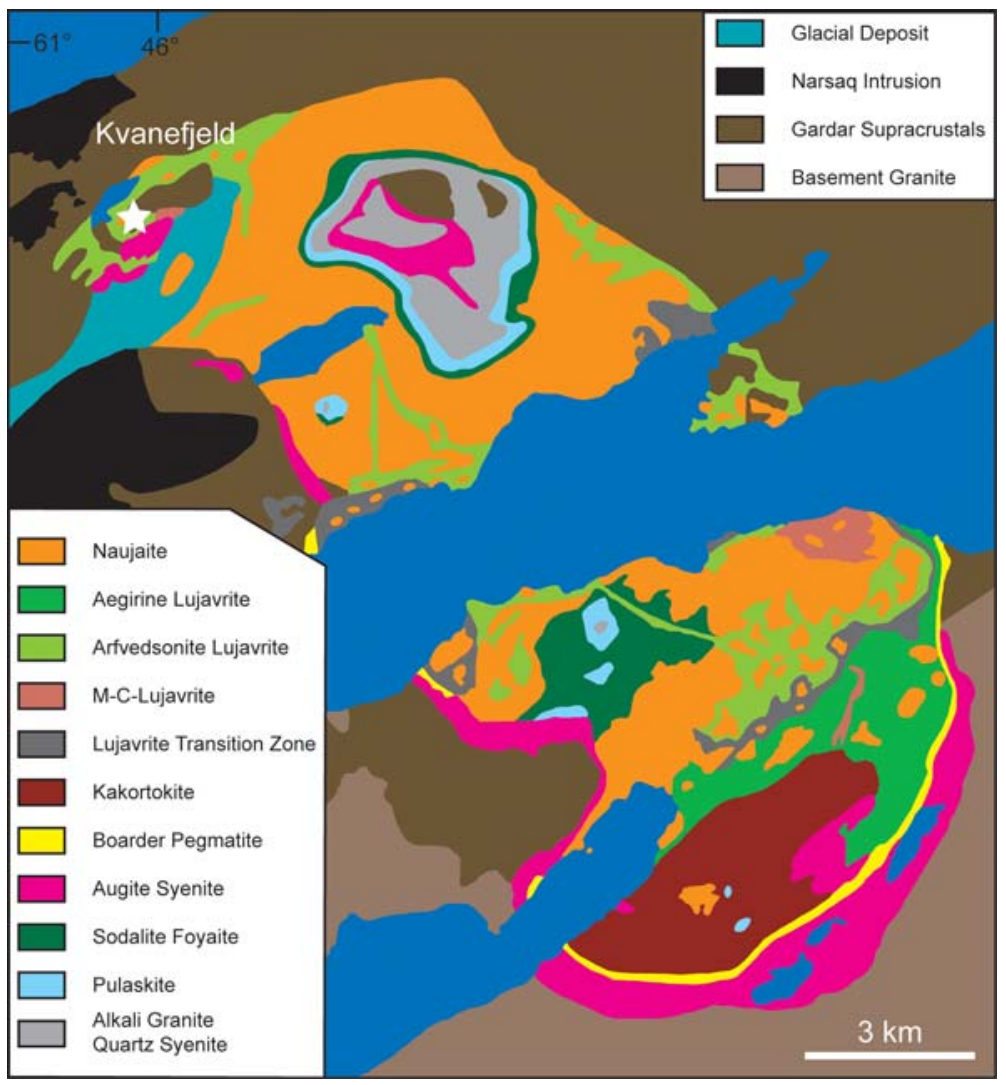

FIG. 1. Geological map of Ilímaussaq alkaline complex modified after Sørensen (2001).

Tajikistan (Agakhanov et al., 2003) and Sokolova et al., (2003) described the structure in detail. Until now, Dara-i-Pioz is the only locality where moskvinite-(Y) has been observed. It occurs intergrown between reedmergnerite, telyushenkoite and an unidentified Y silicate (Agakhanov et al., 2003).

The present work describes the first occurrence of moskvinite-(Y) in Greenland from the new drilling campaigns carried out on Kvanefjeld. In addition, some general implications of the REE mineralogy of Ilímaussaq are discussed in relation to primary mineralogy and late-stage alteration as well as fluid compositions. Furthermore, the first occurrence of a $\mathrm{K}-\mathrm{Fe}$ sulfide in Ilímaussaq is discussed.

\section{Analytical methods}

\section{Electron probe microanalysis (EPMA)}

The major elements were determined by EPMA using the Cameca SX100 electron microprobe, at the Department of Geosciences, University of Oslo, operating in wavelength-dispersion mode with an acceleration voltage of $20 \mathrm{kV}$ and a beam current of $15 \mathrm{nA}$. The electron beam was defocused to a diameter of $5 \mu \mathrm{m}$ to minimize the effects of alkali mobility in the samples resulting from beamsample interaction. Moskvinite-(Y) did not show beam damage at these conditions, but typically a bright blue and slowly fading cathodoluminescence was observed. The following calibration standards were used: wollastonite $(\mathrm{Si})$, albite $(\mathrm{Na})$, orthoclase $(\mathrm{K})$ and synthetic orthophosphates (Y, Gd, Dy, Er and Yb) (Jarosewich and Boatner, 1991; Donovan et al., 2003). Intensity data were corrected for inter-element overlaps, and for matrix effects using the PAP procedure (Pouchou and Pichoir, 1984). The samples were checked using a scanning electron microscope with energydispersive spectroscopy (SEM-EDS) to make sure no other elements, than those analysed were present in the mineral. 


\section{MOSKVINITE-(Y) FROM THE ILÍMAUSSAQ ALKALINE COMPLEX}

\section{Laser ablation inductively coupled plasma mass spectrometry (LA-ICP-MS)}

Trace elements and REE were analysed with an Agilent 7700 Series quadrupole ICP-MS connected to a Resonetics RESOlution M-50-LR laser ablation unit equipped with a $193 \mathrm{~nm}$ Coherent COMPex Pro 110 laser based at the Pacific Center for Isotopic and Geochemical Research at the University of British Columbia. To minimize detector overload a $13 \mu \mathrm{m}$ beam was used during data collection. The data were processed using the IGOR Pro software (WaveMetrics, wavemetrics.com). The NIST 612 and ATHO standards were used to monitor instrument drift during the analytical session and Si from EPMA as an internal standard. Table 1 presents the compositional data and the formula calculated based on 15 oxygens with a comparison of moskvinite-(Y) from Dara-i-Pioz.

\section{Energy-dispersive spectrometry}

Semi-quantitative EDS analyses were carried out on a Hitachi S-3600 low vacuum SEM equipped with a Bruker XFlash 5030 Silicon Drift Detector (SSD), housed at the Natural History Museum, Oslo. Well-characterized zeolites from the mineral collection at the Natural History Museum were used to confirm the zeolite identifications by this semiquantitative EDS method.

\section{Occurrence}

Moskvinite-(Y) was discovered in sample K_M010_130, which is from the metallurgical drill core K_M010 at a depth of $130 \mathrm{~m}$ (core hole collar UTM $23 \mathrm{~V} 446255 \mathrm{mE} 6760294 \mathrm{mN}$ ). The rock is a homogeneous arfvedsonite lujavrite containing arfvedsonite, nepheline, sodalite, albite, aegirine, steenstrupine-(Ce) and natrolite. Moskvinite-(Y) occurs together with a mineral of the britholite group in pseudomorphs after an unknown primary mineral. Figure $2 a$ shows that alteration of arfvedsonite to aegirine has taken place around the pseudomorphs containing moskvinite, but also around steenstrupine-(Ce) and lovozeritegroup minerals, both of which have been altered. Figure $2 b$ shows aegirine partly to fully replacing

TABLE 1. Composition of moskvinite-(Y) from Ilímaussaq and Dara-i-Pioz.

\begin{tabular}{|c|c|c|c|c|}
\hline \multirow{3}{*}{$n$} & \multicolumn{2}{|c|}{ Ilímaussaq } & \multicolumn{2}{|c|}{ Dara-i-Pioz $^{\#}$} \\
\hline & \multicolumn{2}{|c|}{19} & \multicolumn{2}{|c|}{6} \\
\hline & Wt.\% & a.p.f.u. & Wt.\% & a.p.f.u. \\
\hline $\mathrm{SiO}_{2}$ & $60.2(6)$ & 5.98 & 60.34 & 6.00 \\
\hline $\mathrm{Na}_{2} \mathrm{O}$ & $10.1(1)$ & 1.94 & 10.66 & 2.06 \\
\hline $\mathrm{K}_{2} \mathrm{O}$ & $7.8(1)$ & 0.99 & 7.50 & 0.95 \\
\hline $\mathrm{Y}_{2} \mathrm{O}_{3} *$ & 17.7 & 0.94 & 14.63 & 0.77 \\
\hline $\mathrm{La}_{2} \mathrm{O}_{3} *$ & - & - & & \\
\hline $\mathrm{Ce}_{2} \mathrm{O}_{3} *$ & - & - & & \\
\hline $\mathrm{Pr}_{2} \mathrm{O}_{3} *$ & - & - & & \\
\hline $\mathrm{Nd}_{2} \mathrm{O}_{3} *$ & 0.06 & - & 0.29 & 0.01 \\
\hline $\mathrm{Sm}_{2} \mathrm{O}_{3} *$ & 0.07 & - & 0.54 & 0.02 \\
\hline $\mathrm{Eu}_{2} \mathrm{O}_{3} *$ & - & - & & \\
\hline $\mathrm{Gd}_{2} \mathrm{O}_{3} *$ & 0.23 & 0.01 & 1.13 & 0.04 \\
\hline $\mathrm{Tb}_{2} \mathrm{O}_{3} *$ & 0.08 & - & 0.43 & 0.01 \\
\hline $\mathrm{Dy}_{2} \mathrm{O}_{3} *$ & 0.92 & 0.03 & 2.76 & 0.09 \\
\hline $\mathrm{Ho}_{2} \mathrm{O}_{3} *$ & 0.25 & 0.01 & 0.66 & 0.02 \\
\hline $\mathrm{Er}_{2} \mathrm{O}_{3} *$ & 0.97 & 0.03 & 1.17 & 0.04 \\
\hline $\mathrm{Tm}_{2} \mathrm{O}_{3} *$ & 0.15 & - & & \\
\hline $\mathrm{Yb}_{2} \mathrm{O}_{3} *$ & 0.98 & 0.03 & & \\
\hline $\mathrm{Lu}_{2} \mathrm{O}_{3} *$ & 0.10 & - & & \\
\hline Total & 99.61 & & 100.11 & \\
\hline
\end{tabular}

* LA-ICPMS data; - below detection limit; \# from Agakhanov et al., 2003. 


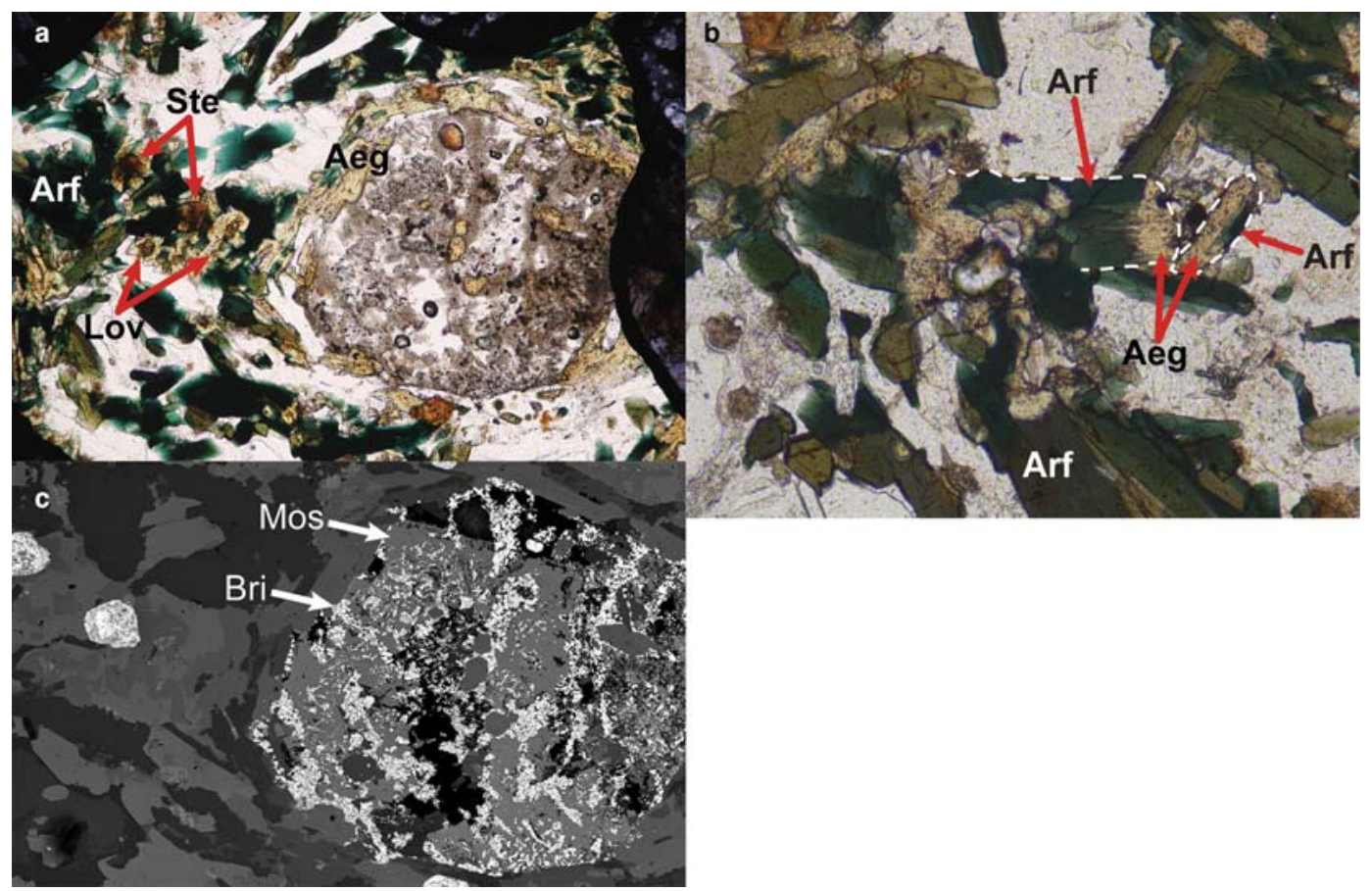

FIG. 2. (a) Photomicrograph (Field of view $2 \mathrm{~mm}$ ) in plane-polarized light showing a moskvinite-(Y) containing pseudomorph surrounded by arfvedsonite replaced by aegirine. (b) Photomicrograph (FOV $=1 \mathrm{~mm})$ in plane-polarized light showing details of aegirine (straw yellow) replacing arfvedsonite (dark green or brownish green) where the original grain boundary of two arfvedsonite crystals have been highlighted by the white dashed line. (c) Back-scatter electron image showing details of the same pseudomorph as in Fig. 2a. Aegirine (Aeg), arfvedsonite (Arf), britholite-group mineral (Bri), lovozerite-group mineral (Lov), moskvinite-(Y) (Mos) and steenstrupine-(Ce) (Ste).

arfvedsonite, which is typical for alteration events in Ilímaussaq (e.g. Ussing 1898; Sørensen et al., 2003). However, the majority of the arfvedsonite in the rock remains unaltered. Microcline and at times natrolite are also present in the moskvinite-(Y) containing pseudomorphs. Moskvinite-(Y) occurs as large, mostly single grains, in pseudomorphs after a mineral that had a hexagonal, platy habit. It has not been possible to find remnants of the primary mineral. A sample from the same core from a depth of $115 \mathrm{~m}$ showed no evidence of moskvinite-(Y) or a mineral, which could be the primary mineral. All pseudomorphs containing moskvinite(Y) also contain small (up to $15 \mu \mathrm{m}$ ) aggregates of a Ca-LREE-phosphosilicate believed to belong to the britholite group (Fig. 2c). Both nepheline and sodalite have experienced alteration along grain boundaries. Semi-quantitative EDS revealed that in both cases natrolite is the newly-formed mineral. When natrolite is replacing sodalite it contains platy grains, up to $10 \mu \mathrm{m}$ in size, of a K-Fe sulfide, which is not observed where natrolite replaced nepheline.

\section{Results}

Table 1 shows that moskvinite-(Y) from Ilímaussaq and from Dara-i-Pioz have similar compositions. The empirical formula of the moskvinite-(Y) from Ilímaussaq, based on 15 oxygens, is $\mathrm{Na}_{1.94} \mathrm{~K}_{0.99}$ $\left(\mathrm{Y}_{0.94} \mathrm{Yb}_{0.03} \mathrm{Er}_{0.03} \mathrm{Dy}_{0.03} \mathrm{Ho}_{0.01} \mathrm{Gd}_{0.01}\right)_{\sum 1.05} \mathrm{Si}_{5.98} \mathrm{O}_{15}$. Moskvinite-(Y) from Ilímaussaq differs in composition to the type material by having a higher $\mathrm{Y}$ and lower $R E E$ content, i.e. it is closer to the endmember composition. The formula has a surplus of $\mathrm{Y}+R E E$ (1.05 a.p.f.u.) while there is a deficiency of $\mathrm{Na}$ (1.94 a.p.f.u.) indicating that some $R E E$ enter the Na site. Figure 3 shows an EDS spectrum of the $\mathrm{K}-\mathrm{Fe}$ sulfide and that $\mathrm{K}, \mathrm{Fe}$ and $\mathrm{S}$ are the main elements with minor Cl. Semi-quantitative analyses gave a $\mathrm{Fe} / \mathrm{K}$ ratio of $\sim 4$. The $\mathrm{Cl}$ is related to the 


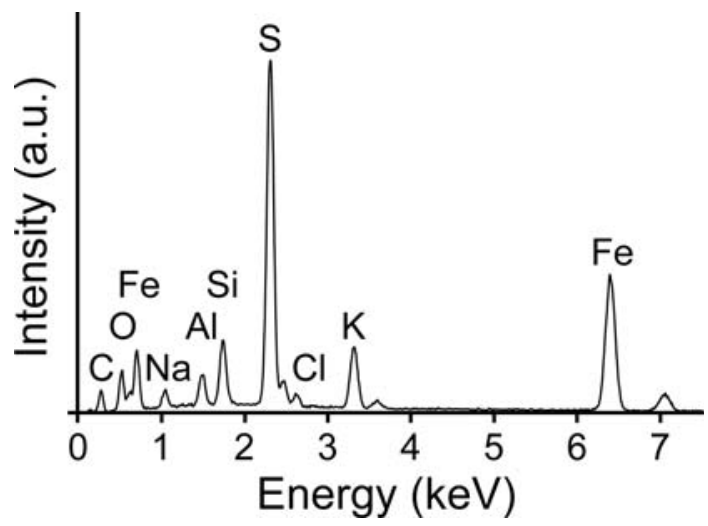

FIG. 3. Semi-quantitative EDS spectrum of the chlorbartonite-bartonite group mineral. Sodium, Al and Si are from the surrounding natrolite and $\mathrm{C}$ is from the coating.

sulfide as the surrounding natrolite does not contain any $\mathrm{Cl}$, whereas $\mathrm{Na}, \mathrm{Al}$ and $\mathrm{Si}$ are from the hosting natrolite.

\section{Discussion}

The lujavrites of Kvanefjeld are enriched in light REE (LREE) compared to heavy REE (HREE) and Y. Bailey et al. (2001) determine the average content of the LREE ( $\mathrm{La}, \mathrm{Ce}$ and $\mathrm{Nd}$ ) for aegirine lujavrite, arfvedsonite lujavrite and m-c-lujavrite to be $3288,10,300$ and $7940 \mathrm{ppm}$, respectively compared to 607,642 and $297 \mathrm{ppm} \mathrm{Y}$ for the same rocks. Therefore, it is not surprising that only $14 \%$ of the REE minerals known from Ilímaussaq are $\mathrm{Y}$ dominated (Table 2). Table 2 is subdivided into three sections indicating the formation of the respective minerals. 'Early magmatic' is defined as minerals that occur in the major rock units and where the textural relations suggest formation during early crystallization of the rocks. 'Late magmatic' is a term that covers minerals formed in pegmatites and hydrothermalites. The term hydrothermalite used here is as defined by Khomyakov, (1995) as late-stage veins and altered rocks containing hydrous aluminosilicates such as ussingite $\left(\mathrm{Na}_{2} \mathrm{AlSi}_{3} \mathrm{O}_{8} \mathrm{OH}\right)$. Minerals of 'secondary' nature are those where either texture or paragenesis clearly indicates an origin related to alteration of the primary rock/mineral. The distinction between late magmatic and secondary can at times be difficult. Table 2 reveals that most of the REE minerals in Ilímaussaq occur in restricted parageneses, with nacareniobsite-(Ce) being the only mineral occurring in all three sub groups. Interestingly, all the yttrium-dominated minerals are secondary in nature. This raises the question of the origin of the $\mathrm{Y}$ forming the $\mathrm{Y}$ minerals in Ilímaussaq. Do the $Y$ minerals form as a result of external fluids rich in Y or are they a result of processes occurring within Ilímaussaq? Studies of eudialyte (e.g. KarupMøller et al., 2010; Borst et al., 2015) show that the alteration of eudialyte results in a fractionation of $R E E$ from the primary mineral into distinct minerals hosting $L R E E$, HREE, Y and $\mathrm{Zr}$, respectively. It is worth noting that: (1) moskvinite-(Y) from Ilímaussaq is close to the ideal Y-dominated composition with less REE than moskvinite-(Y) from Dara-i-Pioz; (2) it appears in grains with a hexagonal outline regardless that it is a monoclinic mineral; (3) moskvinite-(Y) is always associated with a LREE dominated mineral; (4) the sample does not show signs of later veins with a $Y$ mineralogy. This indicates that the $\mathrm{Y}$ in moskvinite$(\mathrm{Y})$ is not from an external source, but from the replacement of a primary $R E E$ mineral. From Table 2 it is not possible to define what the precursor mineral was, but in all likelihood it would have been dominated by LREE. The platy and hexagonal morphology of the pseudomorphs is similar to that of eudialyte, making it a potential precursor mineral. However, studies of eudialyte alteration from Ilímaussaq (e.g. Karup-Møller et al., 2010; Borst et al., 2015) clearly show that $\mathrm{Zr}$ is retained within the pseudomorphs forming predominantly catapleiite. There is no evidence of $\mathrm{Zr}$-phases in the moskvinite-(Y) pseudomorphs excluding eudialyte as a precursor mineral. Furthermore, the $R E E$ content in primary eudialyte is low and therefore only minor amounts of $R E E$ minerals are formed during the alteration of 
TABLE 2. Parageneses of $R E E$ minerals in Ilímaussaq.

\begin{tabular}{lccc}
\hline & $\begin{array}{c}\text { Early } \\
\text { Mineral }\end{array}$ & $\begin{array}{c}\text { Late } \\
\text { magmatic } \\
\text { magmatic }\end{array}$ & Secondary \\
\hline Dyrnaesite-(La) & $\mathrm{x}$ & & \\
Nacareniobsite-(Ce) & $\mathrm{x}$ & $\mathrm{x}$ & $\mathrm{x}$ \\
Sazhinite-(Ce) & $\mathrm{x}$ & & \\
Steenstrupine-(Ce) & $\mathrm{x}$ & $\mathrm{x}$ & $\mathrm{x}$ \\
Vitusite-(Ce) & $\mathrm{x}$ & $\mathrm{x}$ & \\
Ancylite-(La) & & $\mathrm{x}$ & \\
Bastnäsite-(Ce) & & $\mathrm{x}$ & $\mathrm{x}$ \\
Britholite-(Ce) & & $\mathrm{x}$ & \\
Carlgieseckeite-(Nd) & & $\mathrm{x}$ & \\
Ilimaussite-(Ce) & & $\mathrm{x}$ & \\
Joaquinite-(Ce) & & $\mathrm{x}$ & \\
Kuannersuite-(Ce) & & $\mathrm{x}$ & \\
Orthojoaquinite-(La) & & $\mathrm{x}$ & \\
Semenovite-(Ce) & & $\mathrm{x}$ & \\
Stillwellite-(Ce) & & $\mathrm{x}$ & \\
Synchysite-(Ce) & & $\mathrm{x}$ & \\
Tundrite-(Ce) & & $\mathrm{x}$ & \\
Tundrite-(Nd) & & & $\mathrm{x}$ \\
Allanite-(Ce) & & & $\mathrm{x}$ \\
Calcioancylite-(Ce) & & & $\mathrm{x}$ \\
Cerianite-(Ce) & & & $\mathrm{x}$ \\
Cerite-(Ce) & & $\mathrm{x}$ \\
Fergusonite-(Ce) & & & $\mathrm{x}$ \\
Fergusonite-(Y) & & & $\mathrm{x}$ \\
Kainosite-(Y) & & & $\mathrm{x}$ \\
Monazite-(Ce) & & & $\mathrm{x}$ \\
Moskvinite-(Y) & & & $\mathrm{x}$ \\
Rhabdophane-(Ce) & & & \\
Xenotime-(Y) & & & \\
& & & \\
\hline
\end{tabular}

Ilímaussaq is the type locality for the minerals in bold.

eudialyte (Karup-Møller et al., 2010; Borst et al., 2015). Abenakiite-(Ce), $\mathrm{Na}_{26} R E E_{6}\left(\mathrm{SiO}_{3}\right)_{6}\left(\mathrm{PO}_{4}\right)_{6}$ $\left(\mathrm{CO}_{3}\right)_{6}\left(\mathrm{SO}_{2}\right) \mathrm{O}$, is another potential candidate, but this mineral has only been found as a single grain from Mont Saint-Hilaire in Canada (McDonald et al., 1994). The composition of abenakiite-(Ce) could be the source of both Si to moskvinite-(Y) and $\mathrm{P}$ for the britholite-group mineral in the pseudomorphs. The $\mathrm{S}$ and $\mathrm{C}$ from abenakiite-(Ce) could have ben lost during the alteration and with the high $\mathrm{Na}$ content the structure may allow for some $\mathrm{K}$, which could be incorporated in the late moskvinite-(Y). Although the composition of abenakiite-(Ce) is not ideal for being the precursor mineral, e.g. the lack of $\mathrm{K}$, it is possible that the $\mathrm{K}$ in moskvinite-( $\mathrm{Y})$ has a different origin (see discussion below). When exploring the potential precursor mineral it is important to bear in mind that the mineralogical complexity of Ilímaussaq makes it highly likely that the precursor mineral was a species not yet known to science.

\section{Alteration of feldspathoids}

Natrolite and analcime are both abundant alteration minerals after feldspathoids in Ilímaussaq (e.g. Ussing, 1912; Markl and Baumgartner, 2002). To understand the nature of the fluid causing the alteration it is necessary to bear in mind that replacements in Ilímaussaq are typically volume conserving (Markl and Baumgartner, 2002). The moskvinite-(Y) sample shows no evidence for either volume expansion or reduction, and therefore only volume conserving reactions will be applied. For simplicity the following calculations are based on the replacement and formation of $100 \mathrm{~cm}^{3}$, which was also used by Markl and Baumgartner, (2002). The major replacements taking place are arfvedsonite (Arf) to aegirine (Aeg), sodalite (Sdl) and nepheline (Nph) to natrolite (Ntr) (see Table 3 for formulae and constants used in the following calculations). The prefixes in the following reactions are the molar amounts involved in replacing and creating the same volume of the respective minerals.

$$
\begin{aligned}
& 0.48 \mathrm{Sdl}+0.35 \mathrm{Si}^{4+}+1.41 \mathrm{O}^{2-}+2.39 \mathrm{H}^{+} \\
& \rightarrow 0.60 \mathrm{Ntr}+0.72 \mathrm{Na}^{+}+0.24 \mathrm{Al}^{3+}+0.48 \mathrm{Cl}^{-}
\end{aligned}
$$

$$
\begin{aligned}
& 0.36 \mathrm{Arf}+0.21 \mathrm{Si}^{4+}+0.64 \mathrm{O}^{2-}+0.47 \mathrm{Na}^{+} \\
& \rightarrow 1.55 \mathrm{Aeg}+0.72 \mathrm{H}^{+}+0.26 \mathrm{Fe}^{2+/ 3+}
\end{aligned}
$$$$
1.87 \mathrm{Nph}+2.39 \mathrm{H}^{+} \rightarrow 0.60 \mathrm{Ntr}+0.68 \mathrm{Na}^{+}
$$

$$
+0.68 \mathrm{Al}^{3+}+0.08 \mathrm{Si}^{4+}+0.33 \mathrm{O}^{2-}
$$

Reaction 1 shows that the replacement of sodalite by natrolite requires additional $\mathrm{Si}, \mathrm{O}$ and $\mathrm{H}$, and produces a surplus of $\mathrm{Na}, \mathrm{Al}$ and $\mathrm{Cl}$, whereas the replacement of arfvedsonite by aegirine consumes $\mathrm{Na}$ and produces $\mathrm{H}$ and $\mathrm{Fe}$ (reaction 2). The replacement of nepheline by natrolite only requires $\mathrm{H}$ and generates $\mathrm{Na}, \mathrm{Al}, \mathrm{Si}$ and $\mathrm{O}$ (reaction 3 ). The hydrogen produced by reaction 2 is not sufficient to generate the amounts of zeolites observed in the sample. Hence the hydrogen must have been introduced via the fluids initiating the alteration. 
Alternatively, the precursor mineral in the moskvinite-(Y) pseudomorphs was hydrated. Both the replacements of sodalite and arfvedsonite require $\mathrm{Si}$, which is produced by the replacement of nepheline by natrolite. However, as with hydrogen, the silica produced by reaction 3 is not enough to fulfil the requirements of reactions 1 and 2 .

The replacement of Cl-bearing minerals (sodalite and eudialyte) in Ilímaussaq generally results in a loss of $\mathrm{Cl}$ (e.g. Karup-Møller et al., 2010; Borst et al., 2015) although secondary sodalite has been observed (Markl et al., 2001). Tugtupite $\left(\mathrm{Na}_{8} \mathrm{Be}_{2} \mathrm{Al}_{2} \mathrm{Si}_{8} \mathrm{O}_{24} \mathrm{Cl}_{2}\right)$ is the only major, secondary chlorine-bearing mineral in Ilímaussaq. Tugtupite is typically an alteration product after chkalovite $\left(\mathrm{Na}_{2} \mathrm{BeSi}_{2} \mathrm{O}_{6}\right)$ (Sørensen et al., 1971), but its abundance (relatively rare) cannot account for all of the chlorine being released. Therefore, the majority of chlorine generated by the replacement reactions is lost from the system. The replacement of arfvedsonite and sodalite both require the addition of $\mathrm{Si}$, and the presence of natrosilite $\left(\mathrm{Na}_{2} \mathrm{Si}_{2} \mathrm{O}_{5}\right)$ in one vein sample (author's material and mentioned in Marks and Markl, 2015) indicates $\mathrm{Na}$-Si-rich fluid as a possible candidate. This is in agreement with studies of the phase relations for various Ilímaussaq minerals (e.g. Andersen and Sørensen, 2005). Alternatively, Markl and Baumgartner, (2002) proposed the formation of $\mathrm{H}_{4} \mathrm{SiO}_{4}$ during reaction of alkaline fluids in Ilímaussaq. The latter would also account for the additional hydrogen required to form the zeolites. Water-soluble minerals such as natrophosphate $\left(\mathrm{Na}_{7}\left(\mathrm{PO}_{4}\right)_{2} \mathrm{~F} \cdot 19 \mathrm{H}_{2} \mathrm{O}\right)$ and dorfmanite $\left(\mathrm{Na}_{2} \mathrm{HPO}_{4} \cdot 2 \mathrm{H}_{2} \mathrm{O}\right)$ have also been described from Ilímaussaq (Petersen et al., 1993, 2001). It is possible that the fluid taking part in the alteration also contained $\mathrm{P}$, which was then incorporated in the britholite-like mineral associated with moskvinite-(Y). However, the exact nature of the fluid cannot be determined from the current study.
In alkaline systems, $\mathrm{Cl}$ and $\mathrm{F}$-complexes have been shown to take part in REE mobilization and concentration (for a review see Salvi and WilliamsJones, 2004). However, in Ilímaussaq the alteration of primary eudialyte retains the $R E E$ and high-fieldstrength elements (HFSE) in newly-formed minerals within the original grain boundary. The replacement of early magmatic $R E E$ and $\mathrm{Zr}$ minerals generally results in secondary minerals with reduced chemical and structural complexity. Typically, eudialyte is replaced by catapleiite and other minor phases incorporating the $\mathrm{Zr}, R E E$ and $\mathrm{Nb}$ for example monazite-(Ce), nacareniobsite(Ce), fergusonites, britholite-group minerals etc. (e.g. Ussing, 1912; Karup-Møller et al., 2010; Borst et al., 2015). Correspondingly, monazite(Ce), britholite-group minerals, thorite and xenotime-( $\mathrm{Y})$ can form as alteration products of steenstrupine-(Ce) (Makovicky et al., 1980; $\mathrm{H}$. Friis, unpublished data). Migdisov and Williams-Jones, (2014) showed that at elevated $\mathrm{pH}, R E E$ form stable complexes and therefore the mobility of REE is limited at high $\mathrm{pH}$. Borst et al., (2015) argue that this explains why the REE and HFSE are retained during replacement of eudialyte in Ilímaussaq. This is supported by Markl and Baumgartner (2002), who found that the ratio of $\mathrm{Na} / \mathrm{Cl}$ is the most important determinant for $\mathrm{pH}$ in Ilímaussaq fluids and with $\mathrm{Na} / \mathrm{Cl}>1$ the $\mathrm{pH}$ rapidly increased to above 8 . From reaction 1 , it is apparent that the replacement of sodalite by natrolite results in $\mathrm{Na} / \mathrm{Cl} \approx 1.5$, which equals a $\mathrm{pH}>8$, i.e. alkaline (Markl and Baumgartner, 2002). Although $\mathrm{Na}$ is consumed during aegirine formation, which would lead to a reduction in the $\mathrm{Na} / \mathrm{Cl}$ ratio, the replacement of nepheline by natrolite releases additional $\mathrm{Na}$ (reaction 3), and consequently increases the $\mathrm{Na} / \mathrm{Cl}$ ratio and $\mathrm{pH}$. Furthermore, as $\mathrm{Cl}$ leaves the system the $\mathrm{pH}$ is likely to be higher than that estimated based on reaction 1. It is inferred that the high $\mathrm{pH}$ of the alteration caused REE and $\mathrm{Y}$

TABLE 3. Formulae and constants used in the reaction calculations.

\begin{tabular}{llcc}
\hline Mineral & Formula & Molar mass $(\mathrm{g} / \mathrm{mol})$ & Density $\left(\mathrm{g} / \mathrm{cm}^{3}\right)$ \\
\hline Aegirine & $\mathrm{NaFeSi}_{2} \mathrm{O}_{6}$ & 231.00 & 3.59 \\
Analcime & $\mathrm{NaAlSi}_{2} \mathrm{O}_{6} \cdot \mathrm{H}_{2} \mathrm{O}$ & 220.22 & 2.27 \\
Arfvedsonite & $\mathrm{Na}_{3} \mathrm{Fe}_{5} \mathrm{Si}_{8} \mathrm{O}_{22}(\mathrm{OH})_{2}$ & 958.88 & 3.47 \\
Natrolite & $\mathrm{Na}_{2} \mathrm{Al}_{2} \mathrm{Si}_{3} \mathrm{O}_{10} \cdot 2 \mathrm{H}_{2} \mathrm{O}$ & 380.22 & 2.27 \\
Nepheline & $\mathrm{NaAlSiO}_{4}$ & 142.05 & 2.66 \\
Sodalite & $\mathrm{Na}_{4} \mathrm{Al}_{3} \mathrm{Si}_{3} \mathrm{O}_{12} \mathrm{Cl}$ & 484.61 & 2.32 \\
& & & \\
\hline
\end{tabular}


to be retained within the original grain boundaries and $R E E$ being fractionated into new phases, rather than being removed, or introduced, to the system. Yttrium and HREE from the precursor mineral were incorporated into secondary moskvinite-(Y) whereas the LREE formed the secondary britholite-group mineral.

\section{K-Fe sulfide}

Sulfides with $\mathrm{K}$ and $\mathrm{Fe}$ are relatively rare and only five species are recognized namely bartonite $\left(\mathrm{K}_{6} \mathrm{Fe}_{24} \mathrm{~S}_{26}(\mathrm{~S}, \mathrm{Cl})\right)$, chlorbartonite $\left(\mathrm{K}_{6} \mathrm{Fe}_{24} \mathrm{~S}_{26}(\mathrm{Cl}\right.$, $\mathrm{S})$ ), djerfisherite $\left.\mathrm{K}_{6}(\mathrm{Fe}, \mathrm{Cu}, \mathrm{Ni})_{25} \mathrm{~S}_{26} \mathrm{Cl}\right)$, murunskite $\left(\mathrm{K}_{2}(\mathrm{Cu}, \mathrm{Fe})_{4} \mathrm{~S}_{4}\right)$ and rasvumite $\left(\mathrm{KFe}_{2} \mathrm{~S}_{3}\right)$. They typically occur in highly alkaline rocks (e.g. Sokolova et al., 1970; Czamanske et al., 1979; Dobrovolskaya et al., 1981; Lisitsin et al., 2002; Yakovenchuk et al., 2003; Chakhmouradian et al., 2007; Andersen et al., 2012, 2014), carbonatites (e.g. Mitchell, 1997; Jago and Gittins, 1999; Mitchell, 2006), kimberlites (e.g. Clarke et al., 1994; Sharygin et al., 2008), ultramafic rocks (e.g. Czamanske et al., 1981; Zaccarini et al., 2007) and as secondary minerals in metamorphic rocks (e.g. Bianconi et al., 1978; Jamtveit et al., 1997).

The sulfide observed in the natrolite replacing sodalite (Figs 3 and 4) does not correspond to any minerals currently known from Ilímaussaq. Based on the $\mathrm{Fe} / \mathrm{K}$ ratio of $\sim 4$ and the presence of $\mathrm{Cl}$ the mineral is either bartonite or chlorbartonite. If the semi-quantitative data is fixed to $\mathrm{K}=6$ a.p.f.u. then $\mathrm{Cl}$ is 0.85 a.p.f.u. indicating that the mineral is most

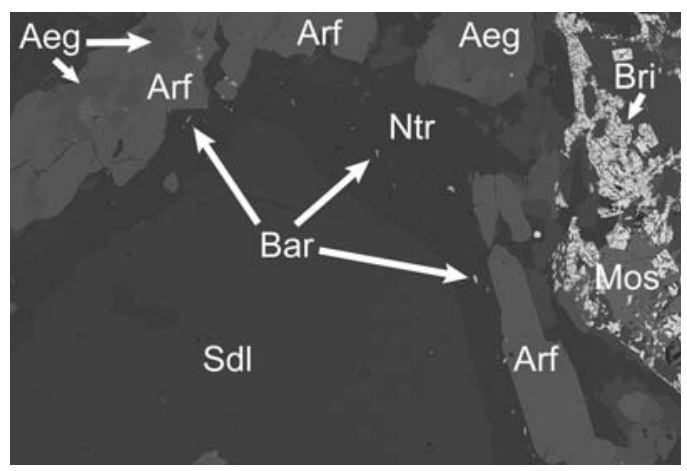

FIG. 4. Back-scatter image showing the chlorbartonitebartonite-group mineral (Bar) in natrolite (Ntr) replacing sodalite ( $\mathrm{Sdl}$ ). Aegirine (Aeg) is replacing arfvedsonite (Arf), which is the slightly brighter of the two. Moskvinite-(Y) (Mos) and britholite-group mineral (Bri). likely chlorbartonite, which has the end-member formula $\mathrm{K}_{6} \mathrm{Fe}_{24} \mathrm{~S}_{26} \mathrm{Cl}$. At the type locality, chlorbartonite occurs with sodalite, natrolite and aegirine in a hydrothermal vein, which is similar to the Ilímaussaq paragenesis (Yakovenchuk et al., 2003). Arfvedsonites in Ilímaussaq typically have high $\mathrm{K}$ content even $>0.5$ a.p.f.u. (Sahama, 1956; Markl, 2001; Sørensen et al., 2003; Pekov et al., 2004), which when altered could be the source of both $\mathrm{K}$ and $\mathrm{Fe}$ in the sulfide. Sodalite at Ilímaussaq typically contains some sulfur in addition to $\mathrm{Cl}$ (Hettmann et al., 2012). The alteration of sodalite could be the source of both $\mathrm{S}$ and $\mathrm{Cl}$ in the sulfide, which explains why the sulfide has only been observed in natrolite formed after sodalite and where arfvedsonite is also being replaced by aegirine. Divalent $\mathrm{Fe}$ in arfvedsonite is being oxidized to form aegirine, however, if the oxygen fugacity was high one would expect that the released $\mathrm{S}$ would also oxidize and form an $\mathrm{Fe}-$ sulfate such as jarosite $\left(\mathrm{KFe}_{3}^{3+}\left(\mathrm{SO}_{4}\right)_{2}(\mathrm{OH})_{6}\right)$. However, the high alkalinity must provide a buffer for the system resulting in coexisting oxidized and reduced elements.

The exact identification of the bartonite-group mineral is not as important as the implications of its presence and distribution in the sample. The fact that the bartonite-group mineral is restricted to the immediate vicinity of sodalite and arfvedsonite being replaced implies that the fluid causing the alteration was slow moving or stagnant. Had the alteration fluid been moving rapidly through the rock, the bartonite-group mineral would have been distributed more evenly as the fluid carried them through the rock. Alternatively, if the fluid moved quickly through the rock, it is likely that it would be homogenized and hence may not provide the conditions for forming the bartonite-group mineral. For these reasons it is inferred that alteration occurred as one initial fluid influx starting the alteration or as a continuous very slow moving fluid influx. Both scenarios would contribute to the low mobility of $R E E$ as the alteration cannot be compared to an active open fluid system. Consequently, alteration parageneses are spatially very localized, contributing to the mineral diversity of Ilímaussaq.

\section{Conclusions}

Moskvinite-(Y) from a lujavrite sample from Kvanefjeld, Ilímaussaq alkaline complex illustrates the mineralogical complexity of Ilímaussaq. The 
lujavrites are distributed throughout the complex and they have a high degree of mineralogical diversity. The current study has shown that the alteration of primary $R E E$ minerals at Kvanefjeld results in a redistribution of the $R E E$ into specific new phases, but without the removal or addition of $R E E$. In other words, the alteration does not influence the grade of critical materials, but only the mineralogy. This is due to the high $\mathrm{pH}$ during alteration, which inhibits the mobility of REE. The fact that moskvinite-(Y) is a secondary mineral follows the general trend from Ilímaussaq, where Y-dominated minerals are all formed as a result of alteration of a primary REE-rich mineral. Furthermore, during alteration there has not been a constant rapid flow of fluid through the rock, as that would have distributed the bartonite-group mineral more widely.

\section{Acknowledgements}

I would like to thank Greenland Minerals and Energy Ltd. for making the core sample available for the current study. The manuscript benefitted from the constructive reviews of Roger Mitchell, Emma Hunt and Kathryn Goodenough. The National Museum of Natural History, Smithsonian Institute is thanked for providing the synthetic REE-phosphate standards. Muriel Erambert is acknowledged for her assistance during EPMA and Shaun Barker for his help with the LA-ICP-MS analyses.

\section{References}

Agakhanov, A.A., Pautov, L.A., Sokolova, E., Hawthorne, F.C. and Karpenko, V.Y. (2003) Moskvinite-(Y), $\quad \mathrm{Na}_{2} \mathrm{~K}(\mathrm{Y}, \mathrm{REE})\left[\mathrm{Si}_{6} \mathrm{O}_{15}\right], \quad$ a new mineral. Zapiski Vsesoyuznogo Mineralogicheskogo Obshchestva, 132, 15-21 [in Russian].

Andersen, T. and Sørensen, H. (2005) Stability of naujakasite in hyperagpaitic melts, and the petrology of naujakasite lujavrite in the Ilímaussaq alkaline complex, South Greenland. Mineralogical Magazine, 69, 125-136.

Andersen, T., Elburg, M.A. and Erambert, M. (2012) Petrology of combeite- and götzenite-bearing nephelinite at Nyiragongo, Virunga Volcanic Province in the East African Rift. Lithos, 152, 105-121.

Andersen, T., Elburg, M.A. and Erambert, M. (2014) Extreme peralkalinity in delhayelite- and andremeyerite-bearing nephelinite from Nyiragongo volcano, East African Rift. Lithos, 206, 164-178.

Bailey, J.C., Gwozdz, R., Rose-Hansen, J. and Sørensen, H. (2001) Geochemical overview of the Ilímaussaq alkaline complex, South Greenland. Pp. 35-53 in The Ilimaussaq alkaline complex, South Greenland: status of mineralogical research with new results (H. Sørensen, editor). Geology of Greenland Survey Bulletin, 190. Geological Survey of Denmark and Greenland, Copenhagen.

Bianconi, F., Haldemann, E.G. and Muir, J.E. (1978) Geology and nickel mineralization of the eastern end of the Finero ultramafic-mafic complex (Ct. Ticino, Swizerland). Schweizerische Mineralogische und Petrographische Mitteilungen, 58, 223-236.

Borst, A.M., Friis, H., Andersen, T., Nielsen, T.F.D., Waight, T.E. and Smit, M.A. (2015) Zirconosilicates in the kakortokites of the Ilímaussaq complex, South Greenland: Implications for fluid evolution and high-field-strength and rare-earth element mineralization in agpaitic systems. Mineralogical Magazine, 80, 5-30.

Chakhmouradian, A.R., Halden, N.M., Mitchell, R.H. and Horváth, L. (2007) Rb-Cs-rich rasvumite and sectorzoned "loparite-(Ce)" from Mont Saint-Hilaire (Québec, Canada) and their petrologic significance. European Journal of Mineralogy, 19, 533-546.

Clarke, D.B., Mitchell, R.H., Chapman, C.A.T. and MacKay, R.M. (1994) Occurrence and origin of djerfisherite from the Elwin Bay kimberlite, Somerset Island, Northwest Territory. The Canadian Mineralogist, 32, 815-823.

Czamanske, G.K., Erd, R.C., Sokolova, M.N., Dobrovol'skaya, M.G. and Dmitrieva, M.T. (1979) New data on rasvumite and djerfisherite. American Mineralogist, 64, 776-778.

Czamanske, G.K., Erd, R.C., Leonard, B.F. and Clark, J. R. (1981) Bartonite, a new potassium iron sulfide mineral. American Mineralogist, 66, 369-375.

Dobrovolskaya, M.G., Tsepin, A.I., Evstigneeva, T.L., Vyal'sov, L.N. and Zaozerina, A.O. (1981) Murunskite, $\mathrm{K}_{2} \mathrm{Cu}_{3} \mathrm{FeS}_{4}$, a new sulfide of potassium, copper and iron. Zapiski Vsesoyuznogo Mineralogicheskogo Obshchestva, 110, 468-473 [in Russian].

Donovan, J.J., Hanchar, J.M., Picolli, P.M., Schrier, M.D., Boatner, L.A. and Jarosewich, E. (2003) A reexamination of the rare-earth-element orthophosphate standards in use for electron-microprobe analysis. The Canadian Mineralogist, 41, 221-232.

Ferguson, J. (1964) Geology of the Ilímaussaq alkaline intrusion, South Greenland - Description of map and structure. Meddelelser Om Grønland, 172, 1-82.

Hettmann, K., Wenzel, T., Marks, M. and Markl, G. (2012) The sulfur speciation in S-bearing minerals: New constraints by a combination of electron microprobe analysis and DFT calculations with special reference to sodalite-group minerals. American Mineralogist, 97, 1653-1661.

Jago, B.C. and Gittins, J. (1999) Mn- and F-bearing rasvumite in natrocarbonatite at Oldoinyo Lengai volcano, Tanzania. Mineralogical Magazine, 63, 53-55. 
Jamtveit, B., Dahlgren, S. and Austrheim, H. (1997) Highgrade contact metamorphism of calcareous rocks from the Oslo Rift, southern Norway. American Mineralogist, 82, 1241-1254.

Jarosewich, E. and Boatner, L.A. (1991) Rare-earth element reference samples for electron microprobe analysis. Geostandards Newsletter, 15, 397-399.

Karup-Møller, S., Rose-Hansen, J. and Sørensen, E. (2010) Eudialyte decomposition minerals with new hitherto undescribed phases from the Ilímaussaq complex, South Greenland. Bulletin of the Geological Society of Denmark, 58, 75-88.

Khomyakov, A.P. (1995) Mineralogy of Hyperagpaitic Alkaline Rocks. 1st. Edition. Oxford University Press, Oxford, pp. 223.

Krumrei, T.V., Villa, I.M., Marks, M.A.W. and Markl, G. (2006) $\mathrm{A}{ }^{40} \mathrm{Ar} /{ }^{39} \mathrm{Ar}$ and $\mathrm{U} / \mathrm{Pb}$ isotopic study of the Ilímaussaq complex, South Greenland: Implications for the ${ }^{40} \mathrm{~K}$ decay constant and for the duration of magmatic activity in a peralkaline complex. Chemical Geology, 227, 258-273.

Lisitsin, D.V., Dobrovol'skaya, M.G., Tsepin, A.I., Shcherbachev, D.K., Trubkin, N.V. and Kononkova, N.N. (2002) Sulfide mineralization in high-alkaline pegmatites of the Koashva deposit (Khibiny Massif, Kola Peninsula). Geology of Ore Deposits, 44, 385-395.

Makovicky, M., Makovicky, E., Leth Nielsen, B., KarupMøller, S. and Sørensen, E. (1980) Mineralogical, radiographic and uranium leaching studies on the uranium ore from Kvanefjeld, Ilimaussaq, South Greenland. Risoe-R, No. 416. Forskningscenter Risoe, Denmark.

Markl, G. (2001) A new type of silicate liquid immiscibility in peralkaline nepheline syenites (lujavrites) of the Ilímaussaq complex, South Greenland. Contributions to Mineralogy and Petrology, 141, 458-472.

Markl, G. and Baumgartner, L. (2002) pH changes in peralkaline late-magmatic fluids. Contribution to Mineralogy and Petrology, 144, 331-346.

Markl, G., Marks, M., Schwinn, G. and Sommer, H. (2001) Phase equilibrium constraints on intensive crystallization parameters of the Ilímaussaq complex, South Greenland. Journal of Petrology, 42, 2231-2258.

Marks, M.A.W. and Markl, G. (2015) The Ilímaussaq alkaline complex, South Greenland. Pp. 649-691 in: Layered Intrusions (B. Charlier, O. Namur, R. Latypov and C. Tegner, editors). Springer Verlag, Dordrecht, The Netherlands.

McDonald, A.M., Chao, G.Y. and Grice, J.C. (1994) Abenakiite-(Ce), a new silicophospate carbonate mineral from Mont Saint-Hilaire, Quebec: description and structure determination. The Canadian Mineralogist, 32, 843-854.
Migdisov, A.A. and Williams-Jones, A.E. (2014) Hydrothermal transport and deposition of the rare earth elements by fluorine-bearing aqueous liquids. Mineralium Deposita, 49, 987-997.

Mitchell, R.H. (1997) Carbonate-carbonate immiscibility, neighborite and potassium iron sulphide in Oldoinyo Lengai natrocarbonatite. Mineralogical Magazine, 61, 779-789.

Mitchell, R.H. (2006) Sylvite and fluorite microcrysts, and fluorite-nyerereite intergrowths from natrocarbonatite, Oldoinyo Lengai, Tanzania. Mineralogical Magazine, 70, 103-114.

Pekov, I.V., Chukanov, N.V., Lebedeva, Y.S., Pushcharovsky, D.Y., Ferraris, G., Gula, A., Zadov, A.E., Novakova, A.A. and Petersen, O.V. (2004) Potassicarfvedsonite, $\mathrm{KNa}_{2} \mathrm{Fe}_{4}^{2+} \mathrm{Fe}^{3+} \mathrm{Si}_{8} \mathrm{O}_{22}(\mathrm{OH})_{2}$, a $\mathrm{K}$-dominant amphibole of the arfvedsonite series from agpaitic pegmatites - Mineral data, structure refinement and disorder in the $A$ site. Neues Jahrbuch für Mineralogie - Monatshefte, 555-574.

Petersen, O.V., Johnsen, O., Bernhardt, H.J. and Medenbach, O. (1993) Dorfmanite, $\mathrm{Na}_{2} \mathrm{HPO}_{4} \cdot 2 \mathrm{H}_{2} \mathrm{O}$, from the Ilímaussaq Alkaline Complex, South Greenland. Nenes Jahrbuch für Mineralogie - Monatshefte, 254-258.

Petersen, O.V., Khomyakov, A.P. and Sørensen, H. (2001) Natrophosphate from the Ilímaussaq alkaline complex, South Greenland. Pp. 139-141 in: The Ilimaussaq alkaline complex, South Greenland: status of mineralogical research with new results $(\mathrm{H}$. Sørensen, editor). Geology of Greenland Survey Bulletin, 190. Geological Survey of Denmark and Greenland, Copenhagen.

Pouchou, J.L. and Pichoir, F. (1984) Quantitative microanalytic possibilities using a new formulation of matrix effects. Journal de Physique, 45, 17-20.

Sahama, T.G. (1956) Optical anomalies in arfvedsonite from Greenland. American Mineralogist, 41, 509-512.

Salvi, S. and Williams-Jones, A.E. (2004) Alkaline granite-syenite deposits. Pp. 315-341 in: RareElement Geochemistry and Mineral Deposits (R.L. Linnen and I.M. Samson, editors). Short Course Notes, 17. Geological Association of Canada, Ontario.

Sharygin, V.V., Kamenetsky, V.S. and Kamenetsky, M.B. (2008) Potassium sulfides in kimberlite-hosted chloride-"nyerereite" and chloride clasts of UdachnayaEast pipe, Yakutia, Russia. The Canadian Mineralogist, 46, 1079-1095.

Sokolova, E., Hawthorne, F.C., Agakhanov, A.A. and Pautov, L.A. (2003) The crystal structure of moskvinite-(Y), $\mathrm{Na}_{2} \mathrm{~K}(\mathrm{Y}, \mathrm{REE}) \mathrm{Si}_{6} \mathrm{O}_{15}$, a new silicate mineral with $\mathrm{Si}_{6} \mathrm{O}_{15}$ three-membered double rings from the Dara-i-Pioz moraine, Tien-Shan mountains, Tajikistan. The Canadian Mineralogist, 41, 513-520.

Sokolova, M.N., Dobrovol'skaya, M.G., Organova, N.I. and Dimitrik, A.L. (1970) A sulfide of iron and 


\section{MOSKVINITE-(Y) FROM THE ILÍMAUSSAQ ALKALINE COMPLEX}

potassium, the new mineral rasvumite. Zapiski Vsesoyuznogo Mineralogicheskogo Obshchestva, 99, $712-720$.

Sørensen, H. (1992) Agpaitic nepheline syenites - a potential source of rare elements. Applied Geochemistry, 7, 417-427.

Sørensen, H. (2001) Brief introduction to the geology of the Ilímaussaq alkaline complex, South Greenland, and its exploration history. Pp. 7-23 in: The Ilimaussaq alkaline complex, South Greenland: status of mineralogical research with new results $(\mathrm{H}$. Sørensen, editor). Geology of Greenland Survey Bulletin, 190. Geological Survey of Denmark and Greenland, Copenhagen.

Sørensen, H., Danø, M. and Petersen, O.V. (1971) On the mineralogy and paragenesis of tugtupite $\mathrm{Na}_{8} \mathrm{Al}_{2} \mathrm{Be}_{2} \mathrm{Si}_{8} \mathrm{O}_{24}(\mathrm{Cl}, \mathrm{S})_{2}$, from Ilímaussaq Alkaline Intrusion, South Greenland. Meddelelser Om Grønland, 181, 1-38.

Sørensen, H., Bailey, J.C., Kogarko, L.N., Rose-Hansen, J. and Karup-Møller, S. (2003) Spheroidal structures in arfvedsonite lujavrite, Ilímaussaq alkaline complex, South Greenland - an example of macro-scale liquid immiscibility. Lithos, 70, 1-20.

Sørensen, H., Bailey, J.C. and Rose-Hansen, J. (2011) The emplacement and crystallization of the U-Th-REErich agpaitic and hyperagpaitic lujavrites at Kvanefjeld, Ilímaussaq alkaline complex, South
Greenland. Bulletin of the Geological Society of Denmark, 59, 69-92.

Upton, B.G.J. (2013) Tectono-magmatic evolution of the younger Gardar southern rift, South Greenland. Geological Survey of Denmark and Greenland Bulletin, 29, 1-124.

Ussing, N.V. (1898) Mineralogical and petrographic investigations of Greenlandic nepheline syenites and related rocks. Meddelelser Om Grønland, 14, 1-220 [in Danish].

Ussing, N.V. (1912) Geology of the country around Julianehaab, Greenland. Meddelelser Om Grønland, 38, $1-426$.

Waight, T., Baker, J. and Willigers, B. (2002) Rb isotope dilution analyses by MC-ICPMS using $\mathrm{Zr}$ to correct for mass fractionation: towards improved $\mathrm{Rb}-\mathrm{Sr}$ geochronology? Chemical Geology, 186, 99-116.

Yakovenchuk, V.N., Pakhomovsky, Y.A., Men'shikov, Y.P., Ivanyuk, G.Y., Krivovichev, S.V. and Burns, P.C. (2003) Chlorbartonite, $\mathrm{K}_{6} \mathrm{Fe}_{24} \mathrm{~S}_{26}(\mathrm{Cl}, \mathrm{S})$, a new mineral species from a hydrothermal vein in the Khibina massif, Kola peninsula, Russia: Description and crystal structure. The Canadian Mineralogist, 41, 503-511.

Zaccarini, F., Thalhammer, O.A.R., Princivalle, F., Lenaz, D., Stanley, C.J. and Garuti, G. (2007) Djerfisherite in the Guli dunite complex, Polar Siberia: a primary or metasomatic phase? The Canadian Mineralogist, 45, 1201-1211. 